УДК 351.761.3+343.575(439)

DOI: $10.19073 / 2658-7602-2020-17-4-485-494$

АНТИНАРКОТИЧЕСКАЯ ПОЛИТИКА ВЕНГРИИ: СОВРЕМЕННЫЕ ТЕНДЕНЦИИ И ПЕРСПЕКТИВЫ

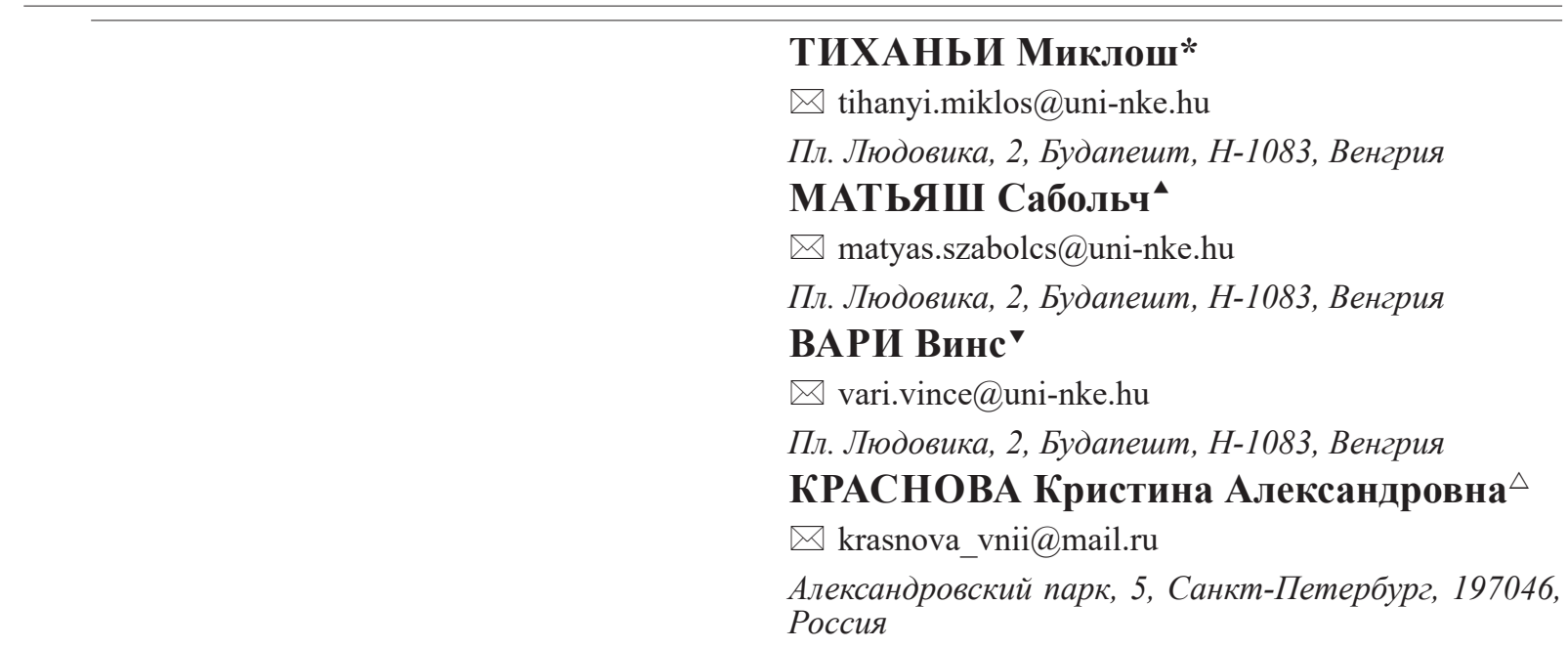

Аннотация. Авторы рассматривают теоретические и прикладные проблемы предотвращения незаконного оборота наркотиков и психотропных веществ в Венгрии в правовом и криминологическом аспектах. Актуальность исследования определяется тем фактом, что Третья стратегия Венгрии в области наркотиков истекает в 2020 году (2013-2020 годы), поэтому необходимо разработать новую стратегию, но пока неизвестно, какие руководящие принципы она будет иметь, какие приоритеты предложат установить в ней.

Данное исследование проводилось с ичелью рассмотрения правовой базы для предотвращения незаконного оборота наркотиков и психотропных веществ и проблемы ее улучшения в Венгрии. Для достижения иеели авторы проанализировали статистику употребления наркотиков, виды и количество наркотиков, изъятых правоохранительными органами за последние пять лет. Авторы описывают наркоситуацию, территориальные особенности употребления наркотиков и многоуровневую систему мер по противодействию незаконному обороту наркотиков и психотропных веществ на национальном уровне. Особое внимание авторы уделяют возрастным и гендерным характеристикам употребления наркотиков, что позволяет выявить наиболее уязвимые группы, которые должны поддерживаться государственными профилактическими программами. Авторы также проанализировали данные о смертности от употребления наркотиков и пришли к выводу, что с 2010 года причинами, в основном, являлись метадон и другие неопиатные препараты.

По результатам исследования были обобщены текущие тенденции употребления наркотиков в Венгрии. Полученные результаты важны для разработки стратегии борьбы с наркотиками и совершенствования законодательства, а также для предупреждения правоохранительных органов как Венгрии, так и других европейских стран.

Ключевые слова: употребление наркотиков, запрет наркотиков, наркополитика, криминализация, Венгрия.

* Доцент факультета правоохранительной деятельности Университета государственной службы, $\mathrm{PhD}$.

^ Доцент факультета правоохранительной деятельности Университета государственной службы, $\mathrm{PhD}$.

> Доцент факультета правоохранительной деятельности Университета государственной службы, PhD.

$\triangle$ Доцент кафедры уголовного права Северо-Западного филиала Российского государственного университета правосудия, кандидат юридических наук, доцент. 


\title{
Drug Policy in Hungary: Current Trends and Future Prospects
}

\author{
Tihanyi Miklós**
}

$\bowtie$ tihanyi.miklos@uni-nke.hu

2 Ludovika tér, Budapest, H-1083, Hungary

Mátyás Szabolcs ${ }^{\boldsymbol{\Lambda}}$

$\bowtie$ matyas.szabolcs@uni-nke.hu

2 Ludovika tér, Budapest, H-1083, Hungary

Vári Vince ${ }^{\mathrm{V}}$

$\bowtie$ vari.vince@uni-nke.hu

2 Ludovika tér, Budapest, H-1083, Hungary

Krasnova Kristina A. $\triangle \triangle$

$\triangle$ krasnova_vnii@mail.ru

5 Alexander Park, St. Petersburg, 197046, Russia

Abstract. The authors consider the theoretical and applied problems of preventing illicit traffic in drugs and psychotropic substances in Hungary in the legal and criminological aspects. The relevance of the study is determined by the fact that the Hungary's third drug strategy expires in 2020 (2013-2020), so a new strategy needs to be developed, but it is not yet known what guidelines it will have, what priorities will be offered to set in it.

The study was conducted with a view to considering the legal framework for the prevention of illicit traffic of drugs and psychotropic substances and the problem of its improvement in Hungary. To achieve this goal, the authors analysed statistics on drug use, types and quantity of drugs seized by law enforcement agencies for the last five years. The authors give a description of the drug situation, territorial features of drug use and a multilevel system of measures to counter illegal traffic in drugs and psychotropic substances at the national level. The authors pay special attention to the age and gender characteristics of drug use, which makes it possible to identify the most vulnerable groups, which should be supported by state preventive programs. The authors also analysed data on mortality from drug use and concluded that from 2010 onwards methadone and other non-opiate drugs predominated in death.

Based on the results of the study, current trends in drug use in Hungary were summarized. The results obtained are important for the development of an anti-drug strategy and the improvement of legislation, as well as for the prevention of law enforcement agencies, both Hungary and other European countries.

Keywords: drug use, drug prohibition, drug policy, criminalisation, Hungary.

Like in most countries, until the beginning of the twentieth century, drug use did not cause health or law enforcement problems in Hungary, so there was no need to treat the problem. By the 1960s, Hun- gary was hit by the demand side of the drug problem. The period from the 1960 s to 1990 can be divided into four major stages based on the quantitative, qualitative, and territorial characteristics of drugs ${ }^{1}$ [7].

** Docent of the Faculty of Law Enforcement at the University of Public Service, $\mathrm{PhD}$.

$\Delta$ Docent of the Faculty of Law Enforcement at the University of Public Service, PhD.

* Docent of the Faculty of Law Enforcement at the University of Public Service, PhD.

$\triangle \Delta$ Docent of the Department of Criminal Law at the North-West branch of the Russian State University of Justice, Candidate of Legal Sciences, Docent.

1 1. From 1945 to the 1960s: For a short time after World War II, the number of drug addicts and drug smugglers increased. The problem did not affect major masses, so law enforcement interventions also proved sufficient to treat it, and a few years later the number of drug users returned to pre-war levels.

2. Period from the 1960s to the early 1970s: From the 1960s to the early 1970s, no scientific survey was conducted on the drug situation at all. One of the "milestones" of the era was the year 1969, when the first drug-related death occurred.

3. The period from the early 1970s to 1973: It was then that the wave of drugs from the United States reached Hungary. During this period, investigations into substance-using youth have already begun. Contemporary sources mention the capital only as a place of use, with large rural cities still considered "drug-free" during this period.

4. The period from 1974 to the early 1980s: The next decade can be considered a period of deconcentration, as this is the period when the capital loses its "monopoly" and drug use also appears in large rural cities [7]. 
The change of regime resulted in significant changes in the field of Hungarian drug crime [3]. In 1988, the so-called world passport was introduced which enabled people to travel all over the world. Many people then came across new drugs in Hungary, such as heroin, LSD, cocaine, marijuana and amphetamines. As a result, the number of drug users increased significantly, but this growth continued at a more moderate pace in the early $2000 \mathrm{~s}^{2}$ [4].

\section{Prevention}

Dealing with the drug problem is not primarily a matter of law enforcement. Reducing the supply of drugs and eliminating drug distributors is clearly the responsibility of law enforcement agencies, but the most important factor in terms of prevention is informing consumers and potential consumers, moreover, teaching and educating them. Activities related to drug prevention in Hungary are coordinated by the Ministry of Human Resources. Most of the organizations working in this field carry out general school activities. About $70 \%$ of them are non-governmental organizations using public funds (mainly from tenders). Outreach work, on the other hand, is mainly carried out by state and municipal organizations $^{3}$.

The police also do important preventive work. Pre-schoolers get OVI-ZSARU, primary school students get $\mathrm{DADA}^{4}$, while most of the high school students are reached through ELLEN-SZER (COUNTER-AGENT) program [12]. The activities of so-called crime prevention consultants are also significant. They come from professional members of the police who work in crime prevention in 3-4 secondary schools on a full-time basis. Local police agencies are in contact with all primary and secondary schools located in their area. Each school is assigned a school police officer who, in addition to his or her police work, performs crime prevention tasks in addition to the programs mentioned above. As part of this, they can get involved in the work of teachers and hold sessions on crime prevention. Despite this, these police officers are not members of the school's board of education. From September 2020, the so-called school guards strengthen the police's crime prevention palette. Although school guards are part of the police force, they do not qualify as professional police officers. Their main tasks are to prevent and interrupt crimes committed in the school area. To this end, they may also use proportionate physical coercion.

2. Legislation and drug policy

2.1. Legal regulations

The emergence of designer drugs has created a new situation in the Hungarian drug market too. The criminals will obviously always be one step ahead the police as the underworld chemists will form more and more compounds of formula that the authority cannot punish.

The Hungarian regulation is extremely forward-looking to alleviate this disadvantage, and it has created one of the most flexible regulations in the European Union. In Hungary, there is no ban on the specific compound, but "only" on the basic formula (generic regulation) [9]. Even in spite of this regulation, it is obvious that the offenders will be ahead of the authority, as the number of chemical variations is so large in the case of the tribal formulas $[2,9]$. In order to allow newly identified psychoactive substances to be added to the ban list even more quickly, the inclusion in the list of prohibited substances was transferred from the government to the Minister of Human Resources as of 1 January 2015 (Decree 55/2014 / XII. 30./EMMI).

2.2. Drug strategies after the regime change

2.2.1. National Strategy for Reducing the Drug Problem (2000-2009) (Decision 96/2000. / XII. 11./ OGY)

After lengthy negotiations, Hungary's first national drug strategy was born at the turn of the millennium, covering the period 2000-2009. Although the strategy had few specifics, it formulated proposals and guidelines for law enforcement agencies (e.g. reducing the number of disco accidents, reducing the supply of drugs through legal and law enforcement means, further developing international law enforcement cooperation). Upon request, Dutch experts also evaluated the work done. External monitoring can be considered exemplary (Hungary was the first in Europe), as it provided an overview of the work and results carried out so far by experts who can be considered impartial and independent.

2.2.2. National Strategy for the Treatment of the Drug Problem (2010-2018), (Decision 106/2009. / XII. 21./ OGY)

The second drug strategy is a framework criminal policy document, but even so, important objectives

\footnotetext{
${ }^{2}$ URL: http://mipszi.hu/cikk/130309-drogfogyasztas-alakulasa-magyarorszagon

${ }^{3}$ URL: http://drogfokuszpont.hu/wp-content/uploads/EMCDDA_jelentes_2018_HU.pdf

${ }^{4}$ Sensing the growing problem, the police launched the so-called DADA program (an acronym formed from the initials of the words smoking-alcohol-drug-AIDS), modeled on the American DARE (drug / abuse / resistance / education) program [8].
} 
can be identified in it (e.g. the need for organizational change and an increase in the number of professionals within the police force; the need to set up a special drug crime service at national level; the need to develop the staff of experts and their technical equipment; the need to step up asset recovery and crime prevention activities). Its implementation could not take place because 80/2013. (X. 16.) OGY repealed it shortly after its entry into force.

2.2.3. National Anti-Drug Strategy 2013-2020, Pure consciousness, sobriety, fight against drug crime (Decision 80/2013. / X. 16./ OGY)

The new strategy was needed mainly because the European Union also had a new strategy, so each Member State also needed a drug strategy for the next period. The development of the new strategy was necessitated by the emergence of a different approach, changes in certain sub-areas (health, education), social and economic changes with a negative impact on addictions and negative changes in substance use (e.g. the emergence and spread of designer drugs) ${ }^{5}$.

The strategy sets general and specific goals in the following areas along the lines of five core values (Right to Life, Human Dignity and Health; Personal and Community Responsibility; Community Activity; Cooperation; Scientific Substantiation): Health promotion and drug prevention; Treatment, care, recovery; Supply reduction. In order to implement the strategy, the government has adopted a policy program based on four pillars: I. Development of the Health promotion and drug prevention system; II. Development of the system of treatment, care, recovery; III. Development of the system of supply reduction interventions; IV. Mobilizing human and social resources. The capital also occupies a prominent place in the field of the drug problem. Naturally, the crowded metropolitan environment is conducive to the distribution of illegal drugs. Therefore, the Budapest Municipality established its own Drug Coordination Forum with the involvement of the Budapest Police Headquarters. The declared goal of the program is to address the drug problem in the capital, not by means of repressive means, but rather by prevention and harm reduction and treatment.

\subsection{Treatment}

A specific area of drug use is the health and social risks, hazards and harms caused by different drugs. The Hungarian legislature recognized at an early stage that, in itself, criminal law instruments were not sufficient to deal with the drug problem. The users themselves are less criminals than people depending on the drug used, who want to break out, forget, or have fun, or who are unable to cope with their mental disorders or problems.

Therefore, in the relatively free-thinking political system that developed after the change of regime, the construction of the care system began. Relying not only on state resources, but also on the involvement of civil society actors, a care system aimed at the treatment of drug addicts has been established. Treatment by definition includes - harm reduction, detoxification and abstinence programs, health and non-health interventions, informal counseling, provision of information and support. Many forms of outpatient and inpatient care and treatment units are available nationwide to care for drug users. The need for specialized outpatient care for drug addicts was recognized in the 1980s, and it was then that the first services were created. The care is typically provided by state / municipally operated public institutions or church / civil non-profit organizations. There are currently no specialized treatment programs, but the existing programs are aimed at consumers of all types of drugs in general, or addictions and people with psychiatric problems in general. An exception to this is opiate substitution treatment, which has been available in Hungary since 1994 for drug users with long-term opiate dependence.

The National Drug Strategy discusses the field of treatment in separate sections and seeks to achieve progress in this field with appropriate objectives. However, it is unfortunate that policy actions are going in the opposite direction to the objectives. Of the goals of Treatment and care, only $22 \%$ were fully met and $64 \%$ were not met at all. The National Drug Focal Point identified 123 actions that would be designed to achieve the strategic objectives. Of these, 8 have been identified as acting entirely against the objectives set. Each of these belongs to the field of treatment.

3. Current trends

3.1. Prevalence of drug varieties

Despite the advancement of designer drugs, "classic" drugs dominate the Hungarian consumption structure. Examining the drug use habits of the adult population, it can be stated that $7.4 \%$ have used marijuana or hashish in their lifetime and $4 \%$ have used ecstasy pills. The proportion of synthetic

\footnotetext{
${ }^{5}$ URL: http://drogfokuszpont.hu/wp-content/uploads/HU_National_Report_2016_HU.pdf
} 
cannabinoids (1.9\%), amphetamines $(1.7 \%)$ and designer drugs $(1.3 \%)$ is much lower. The order of drugs used is the same in the 18-34 age group ${ }^{6}$. The use of new psychoactive substances is highest among the homeless, state-cared for and socially segregated youth. The primary reason for this is to be found in the cheap price and easy availability of the new type of drug. In the case of new psychoactive substances, a new form of appearance is the so-called magic tobacco (a synthetic cannabinoid impregnated on tobacco) and a toothpick (a wooden toothpick impregnated with synthetic cannabinoids) [5]. In any case, it can be considered as a positive fact that intravenous drug use has decreased compared to previous decades, but the injected drug has changed. With the advent of new psychoactive drugs, these marginalized groups have also almost completely switched to new types of drugs (by 2017, $77 \%$ of them had already injected designer drugs).

The main feature of these substances is that they are produced with a slight modification of the chemical formulas of the banned substances in order to avoid official action. As the authorities try to follow these changes by listing more and more compounds, the developers of designers are constantly changing the composition and chemical structure of the materials. Through these ongoing changes, neither distributors nor consumers can know what the composition and effect of the product is actually being marketed and used. This situation, in turn, carries the serious risk that the effects of the drugs are unpredictable, leading to an increase in the number of victims of designer drugs in recent years. Another risk of the constantly changing composition is that doctors and other professionals performing health care do not know which drug caused the toxic symptoms. This also makes the treatment more difficult and risky. It is characteristic of this trend that in May 2020 a new type of agent, 4F-MDMBBICA, appeared in Hungary. Due to the Hungarian pronunciation of the letter line "BICA" at the end of the name of the compound (BIKA means "bull" in Hungarian), the drug became known as "bull". By September of this year, at least 21 people had died from the drug?.

3.2. Age and gender differences in drug use

After the change of regime, the proportion of people who used drugs (especially young people) increased significantly. One in ten $(9.9 \%)$ of the population aged 18-64 and almost one in five young adults aged 18-34 have used drugs in their lifetime $(17.7 \%)$. Most young adults used marijuana and / or hashish $(7.4 \%)$ and $4 \%$ used ecstasy ${ }^{8}$. Among 1516-year olds (grades 9-10), marijuana is the most popular $(18.6 \%)$, followed by new psychoactive substances $(10.1 \%)$. In third place are sedatives and hypnotics consumed without a medical indication $(9 \%)$, followed by analgesics $(7 \%)$. In these cases, concomitant use of alcohol with drugs is also not uncommon ( $8 \%$ ). For all of the above age groups, we can state that the proportion of more expensive, "harder" drugs can be considered relatively low (cocaine, heroin, crack, etc.). Regarding the current trend, the following can be stated. Until 2011, an increase was recorded for most drugs, but by 2015 the trend seemed to reverse, and the number of drug users has clearly decreased since then. Marijuana use decreased the most $(32.5 \%)$, but this was due to the widespread use of designer drugs (cheaper and more readily available, plus the consumption of many varieties was not punishable). There are also significant differences in drug use by gender. While $8.1 \%$ of women have used illicit drugs at least once in their lifetime, this figure is $12.1 \%$ for men?

\subsection{Drugs and mortality}

The number of Hungarian victims who have died due to drug use has been low for years (2017: 33 people). The vast majority of the deceased are men (2017: 1 female), and their average age is 31.3 years, which clearly shows that the problem mainly affects the younger age group in Hungary as well. Interestingly, addiction occurs earlier in women than in men, and even a lower dose is enough to achieve the same effect [12]. The number of deaths indirectly related to drug use in 2017 was 46. Regarding deaths due to drug overdoses, we can state that the new trend after 2010 did not cause a significant change in numbers (the number of deaths fluctuated between 14 and 31 between 2009 and 2019). Moreover, for the years 2010 and 2011, we can register extremely low mortality rates (17 and 14 people). After that, although the number of deaths due to direct overdose increased, far fewer people died as a result of overdose than in the late 1990 s, so drug-related mortality is not currently considered an acute problem in Hungary. In any case,

\footnotetext{
${ }^{6}$ URL: http://drogfokuszpont.hu/wp-content/uploads/EMCDDA_jelentes_2018_HU.pdf

${ }^{7}$ URL: https://hvg.hu/itthon/20200901_bika_dizajnerdrog

${ }^{8}$ URL: http://www.mat.org.hu/doksi/2015/Ā $\bar{b}$ sztraktfuzet_MAT_X_2015.pdf

${ }^{9}$ URL: http://drogfokuszpont.hu/wp-content/uploads/EMCDDA_jelentes_2018_HU.pdf
} 
the change in the mortality structure is noteworthy. While opiates (including heroin) accounted for the largest number of deaths before 2010 (the number of deaths depended on the purity of street heroin), from 2010 onwards methadone and other non-opiate drugs predominated in death ${ }^{10}$.

\subsection{Seized drugs}

The number and volume of drug seizures are two indicators that very sensitively express the severity of the problem. It shows both the degree of activity of law enforcement agencies and structural changes in the drug market. In line with the European trend, 2010 marked a turning point in the drug market in Hungary, too. This is when large quantities of new psychoactive substances appeared. As a result, the share of "classic" drugs has decreased significantly. New types of drugs were more readily available and their prices were also much lower. They accounted for almost $60 \%$ of the drugs seized in 2014. The rate of growth then stopped and nowadays gives about onethird of the drugs seized. Hungary is still a transit country, the cultivation of marijuana or the production of synthetic drugs is not significant ${ }^{11}$ [8]. Since 2017, the proportion of ecstasy tablets containing MDMA and the amount of cocaine ${ }^{12}$ seized have increased slightly. In connection with the latter, we can state that we are facing a European trend, as a similar trend can be observed in many European countries (Table $1^{13}$ ).

\subsection{Drug offenses}

3.5.1. Legal characteristics of drug offenses

The Criminal Code, in force since 2012, is significantly more chiseled in drug crime than under previous criminal laws. Examining the main features of the facts in this context, the following conclusions can be drawn.

The legislator recognized that an internationally recognized list of drugs could easily be circumvented with new types of compounds, so a solution appeared in the domestic regulations according to which a list containing individual compounds and groups - unlike the compounds on the drug list was compiled. Dealer and producer type acts can also be committed on these agents. And since 2014, consumer-type behavior in excess of a small amount has also been a criminal offense. Such conduct, committed to a small or lesser extent, is still not a criminal offense. The perpetrator will only be held liable for a violation. The legislator did not intend to establish the criminal liability of consumers of new psychoactive substances, so consumption is not a crime either. In order for a substance to be included in the list of new psychoactive substances, it must be demonstrated during the preliminary professional evaluation that no data are known to suggest that the substance has a medicinal use and that there is no evidence that the substance poses a similar risk

Type and quantity of drugs seized by law enforcement agencies (police, NAV)

\begin{tabular}{|l|c|c|c|c|c|}
\hline \multicolumn{1}{|c|}{ Type of drug } & 2013 & 2014 & 2015 & 2016 & 2017 \\
\hline Herbal cannabis (kg) & 863,4 & 529,23 & 589,55 & 494,12 & 2139,91 \\
\hline Cannabis plants (plant) & 5307 & 3288 & 2970 & 6482 & 5287 \\
\hline Cannabis resin (kg) & 5 & 7.91 & 18.15 & 3,69 & 114,46 \\
\hline Heroin $(\mathrm{kg})$ & 5,7 & 70,06 & 11,74 & 2,11 & 20,56 \\
\hline Cocaine (kg) & 8,1 & 39,65 & 30,53 & 25,06 & 5,87 \\
\hline Amphetamine (kg) & 74,8 & 15,95 & 32,48 & 24,78 & 24,71 \\
\hline Methamphetamine (kg) & 0,2 & 0,41 & 1,17 & 0,19 & 0,74 \\
\hline Ecstasy tablets (tablet) /MDMA, MDA, MDE/ & 17664 & 13020 & 56420 & 79702 & 51836 \\
\hline LSD (dose) & 342 & 965 & 398 & 928 & 1476 \\
\hline Plant materials with synthetic cannabinoids (kg) & 44,5 & 100,01 & 21,18 & 29,13 & 11,79 \\
\hline Synthetic cannabinoids in powder (kg) & 15,5 & 5,52 & 5,55 & 3,47 & 3,09 \\
\hline Cathinone derivatives in the form of powder (kg) & 81,5 & 42,01 & 18,34 & 36,14 & 30,76 \\
\hline Cathinone derivatives in tablets (tablet) & 55421 & 12902 & 15578 & 3256 & 551 \\
\hline
\end{tabular}

${ }^{10}$ URL: http://drogfokuszpont.hu/wp-content/uploads/EMCDDA_jelentes_2018_HU.pdf

${ }^{11}$ Marijuana comes from the Czech Republic, Albania and the Netherlands, heroin via the Balkan route, cocaine from South America and Western Europe, synthetic drugs from Belgium and the Netherlands, and new psychoactive drugs from China. (URL: http://drogfokuszpont.hu/wp-content/uploads/EMCDDA_jelentes_2018_HU.pdf).

${ }_{12}$ The increase in cocaine is partly due to the fact that its price has remained virtually unchanged for a decade. In 2018, the average street price of heroin in Hungary was 72.9 euros [1].

${ }_{13}$ A lefoglalások laboratóriumi vizsgálati eredményének adatai 2009 és 2017 között. Budapest, NSZKK, 2018. 
to public health, such as substances on drug and psychotropic lists. Individual compounds on the list of new psychoactive substances must be subject to a risk assessment within one year of their inclusion, as a result of which the compound may be included in the psychotropic list. If sufficient data are not available for this, the classification of the new psychoactive substance may be extended for another 1 year. The risk assessment obligation does not apply to groups of compounds that may remain on the list of new psychoactive substances as long as at least one substance belonging to the group of compounds fulfills the conditions of the 17 preliminary professional evaluations.

With the very complex regulation, the legislator wants to provide special protection for minors and children. Juveniles are more susceptible to substance use. Therefore, in order to protect them, the legislature punishes more severely if an adult offender uses a juvenile to commit an act. Penalties for adults who hand over or offer drugs to minors are also more severe.

The penalty is also stricter if the trader-type conduct is carried out in the area of a building intended for educational, public education, child welfare or child protection tasks, or in its immediate vicinity.

Dealer-type behaviors remain at the heart of law enforcement. Criminal law rules treat drug users differently. The cultivation, production, acquisition (hereinafter drug possession) and possession of a drug is normally punishable by 1 to 5 years' imprisonment. In comparison, the regulation seems to be strict in that the basic case of dealer-type behavior can be sanctioned by imprisonment for 2 to 8 years. Possession of a small amount of drugs is a privileged case, so the upper limit of the penalty that can be imposed is lower here. In addition to the above, the legislator acknowledged that most consumer-type behavior is essentially occasional substance use. Therefore, drug use has become a criminal offense as a separate offense. The tightening trend of the Hungarian drug policy is indicated by the fact that even occasional drug use is punishable by up to two years' imprisonment.

Only in the case of consumer-type offenses, the offender shall be released from liability if he or she admits to having committed the offense and proves by a document that he or she has been receiving drug treatment or other care for at least six months, or he/she has participated in a preventive information service. This is not possible if the offender has already participated in such a program within two years prior to the commission of the act. This diversion from the so-called procedural route is possible at both the prosecution and judicial stages. Underlying the drug policy rationale is the consideration that consumers cannot be considered criminals. Broadly speaking, alcohol is also a drug, yet the legislature does not criminalize excessive or problem drinkers. The domestic legislature does not follow any trend of drug liberalization, but accepts that there is no social benefit in punishing consumers.

The peculiarity of drugs is that cultivation or production has a relatively high resource requirement. These devices are, in part, ones that can be kept legally (e.g. a lamp used to grow marijuana, a water circulator, etc.). However, the legislature seeks to prevent these devices from being used for the cultivation or production of drugs. The use of legally possessed devices, materials and equipment for such purposes has criminal relevance.

It has long been known that there are a mass of substances which free trade cannot be banned simply because their misuse may be conducive to the development of an abnormal passion. These are typically household chemical products containing various diluents. Using these chemicals as a pleasure agent does not count as any delicacy. However, there is an increased responsibility on the part of adults to commit a crime if a juvenile or child is taken to enjoy these drugs to their influence.

\subsubsection{Number of crimes}

Since the change of regime, the number of drug users has increased significantly. While before 1989 the goal was to criminalize consumers and distributors, today the primary is to penalize them. Due to the large number of consumers, police capacity does not allow each consumer to be traced. During police proceedings in the case of distributers, 3-4 consumers are "expected" to be questioned by prosecutors and by the court. So that number of people is enough to prove the distribution behaviour, although it is obvious that a dealer does not sell drugs to only 3-4 people, but to many more ones [8].

Despite the increase, we can state that the number of registered drug crimes is still not significant in Hungary. The number of crimes varies between 5,000 and 8,000 (60\% can be linked to cannabis), which accounts for $4.3 \%$ of total crime $(8,640$ crimes were registered in 2018). The majority of drug-related offenders commit consumer-type offenses, with the proportion of distributors below $20 \%{ }^{14}$. Police

\footnotetext{
${ }^{14}$ URL: http://drogfokuszpont.hu/wp-content/uploads/EMCDDA_jelentes_2018_HU.pdf
} 
drug policy documents state that the share of distributor-type behaviour should exceed $25 \%$, but this is formulated as an unrealistic expectation. As long as 3-4 distributors are required to suspect 3-4 consumers in prosecutorial and judicial practice, this is by no means possible. Only with a legal "loophole" it would be possible to increase the proportion of distributor-type behaviour by maintaining the current rate, and this could be a classification of consumer behaviour as a violation [8].

3.6. Territorial characteristics of drug crime

Due to its metropolitan nature, Budapest has been the most infected area for decades. Nearly half of drug-related crimes are tracked in Budapest, and the frequency of crimes above the national average can also be observed in the case of other crimes. Nearly four times as many drug-related crimes are tracked in the city as in the most infected county (Veszprém county). In any case, it is a remarkable fact that in some counties differences in frequency can be observed up to eight times, despite the fact that the drug problem is nowhere near an urban phenomenon, it is present in practically all types of settlements (from big cities to villages). Moreover, in some cumulatively disadvantaged small settlements, the designer drug is an even bigger problem than in larger settlements. In addition to the capital, the most economically developed areas of the country, Veszprém and Komárom-Esztergom counties, are considered to be the most infected, where the proportion of drug-related crimes is almost twice the national average. In the case of counties with below-average development (Jász-Nagykun-Szolnok, Borsod-Abaúj-Zemplén, Heves and Szabolcs-Szatmár-Bereg), the rate of drug crime is below average. This can be explained by several reasons. Designer drugs can be consumed freely until they are banned. Assuming that they largely consume psychoactive substances that are not on the ban list, these people do not commit any offenses, so of course it does not appear in the criminal statistics either. On the other hand, most of these disadvantaged settlements have a small population, where there is usually no police station. In a good case, there is only a district commissioner in the settlement, which definitely hinders the discovery of the problem [8]. There are also significant differences between the consumption habits of different social groups by region. Designer drugs are typically the characteristic pleasure of the lowest social group. Its appeal lies in the fact that it is cheaper to obtain than any alcoholic beverage. Stimulants (MDMA, amphetamine, methamphet- amine) are most favoured by the middle class, especially for weekend entertainment. Cocaine used to be a drug only for iconic athletes and musicians, and remains so today in the upper middle class and among the very wealthy. In many cases, it is a status symbol, so it is mostly used by those who want to express that they can "afford it" [11].

3.7. Characteristics of Organized Crime

3.7.1. Structural characteristics

About $3 / 4$ of those involved in organized crime committed the crime of human trafficking, and 10$10 \%$ of them committed some kind of drug-related crime or counterfeiting. It should be noted, however, that the period under review was the period between 2012 and 2017, when the crime of human trafficking was highly overrepresented, i.e. the proportion of participants in drug-related organized crime in "peacetime" is well above $10 \%$. Examining the offenders by gender, it was found that the proportion of men among offenders is much higher than in the case of "traditional crimes". $13 \%$ of female offenders were convicted of a crime of drug trafficking or drug possession (even in this case, it is true that theproportion of women involved in drug crime would be much higher today due to overrepresented human trafficking). In the case of men, $11 \%$ of the perpetrators were convicted of the same crimes.

The operating time of each organized criminal group was mapped, i.e. how much time elapsed between its establishment and its cessation (police reconnaissance). Of course, this cannot be given exactly by day, only to the nearest month, but nevertheless provides important information to the investigating authority about the organization and conspiracy of a given type of crime, even though in reality it is certainly a few months longer than in the examined time interval. "Organized crime groups involved in drug trafficking have been operating for an average of 18.8 months. However, this value has been raised so much by two groups of offenders, organized not only in a legal sense. One operated for 36 months and the other for 97 months. If we take these two results out, we get a more realistic picture of the duration of organized crime groups involved in drug trafficking. Without them, it is possible to engage in drug trafficking "with impunity" for an average of 6.9 months" [8].

3.7.2. Characteristics of mobility

Examining the mobility of offenders, it was found that the defendants chose almost exclusively land transport (road and rail transport). Preference for land transport may have been primarily for safety reasons. In the case of drug crime, one might think, among 
other things, that it is quite risky to post a larger, drugcontaining package by air. Within land transport, the dominance of road transport can be observed, the role of rail transport is negligible (it did not appear at all in connection with drugs). In the case of drug crime, tourist buses (trusting that many passengers will be less thoroughly controlled), lorries and bicycles can be considered specific within road transport. In connection with the latter means of transport, it has been proven on several occasions that the perpetrators used bicycles within the cities. With regard to the bicycle, it can be assumed that its role in the distribution of drugs within settlements is more significant than even in the Internal Security Fund research. This is because the risk of a cyclist being subjected to police control within a city is extremely low.

The above-mentioned research found that organized crime groups use the motorways in the largaest proportion. Lower category roads, presumably for safety reasons, only rarely in the examined files. It is an extremely interesting fact that the M1 motorway connecting the western border areas of the country with the capital was mentioned in the files in most cases, but was never mentioned in connection with drugs. Nevertheless, we can assume that drug smugglers from Western Europe to Hungary use this route. The fourth most infected road section was the ring road around Budapest (M0 motorway), which can be considered logical due to its geographical location, as this is the road section that surrounds the capital. Half of the crimes that became known here were from some kind of drug-related crime. In summary, more than $80 \%$ of those involved in organized crime used motorways and expressways, meaning that the speed and safety offered by motorways is also an important factor for offenders.

3.8. New trends in trade

After 2010, the domestic and international drug markets underwent a significant transformation.
This is due to the combined effect of two factors. One is the emergence of new types of drugs, which in many cases allow a completely different type of sale than traditional drugs, as they are not on any blacklist and are therefore freely marketable [6]. The other factor is the rapid rise of the World Wide Web in commerce, which has become increasingly viable in recent years [13]. As a result, traders can be eliminated in many cases, so the drug becomes much cheaper and, by the way, the trade is much safer, as the risk of getting caught is lower $[8,10]$. The rise of the internet is illustrated by the fact that the majority of sales on the darknet are already related to drugs, and more than $90 \%$ of the revenue from the darknet market comes from drug sales. As a result of the above, the Hungarian police have established closer co-operation with Magyar Posta and parcel services in order to make more successful reconnaissance. A study examining the crime profile of Hungarian organized crime found that the number of bicycle couriers in large cities is significant, as the risk of getting caught during bicycle traffic is extremely low [8]. New types of distribution include drug delivery by taxi drivers and pizza couriers.

\section{Conclusion}

An analysis of the current drug situation in Hungary at the end of the second decade of the twentyfirst century showed that the spread of illicit consumption of drugs and psychotropic substances continued to be an acute social problem, a factor in undermining demographic and socio-economic potential, as well as a threat to the national security of Hungary. In order to effectively counter the drug trade and destroy its plans to increase the demand for drugs, a comprehensive study of the problem requires the development of a promising and effective system of counter-narcotics in the context of the new millennium within the framework of national antinarcotics strategy for the new period.

\section{References}

1. Bálint R. A kábítószerek utcai árának alakulása 2018-ban. Nemzeti Drog Fókuszpont. 2019.

2. Csesztregi T., Romposné Kovács É. Az új pszichoaktív szerek piacával kapcsolatos friss tapasztalatok. Változó képletek: ÚJ(abb) szerek: kihívások, mintázatok. Budapest, 2017, pp. 145-158.

3. Erdős Á. A Vám- és Pénzügyőrség kábítószer-ellenes tevékenysége a rendszerváltást követő első évtizedben. Rendvédelemtörténeti Füzetek, 2017, no. 27, pp. 15-24.

4. Fürst Z., Wenger T. (Eds.) A kábítószer-abúzus orvosi, jogi és társadalmi vonatkozásai. Budapest, Medicina Publ., 2010. $282 \mathrm{p}$.

5. Kaló Z., Szabó R., Bálint R., Péterfi A., Port Á., Szatmári D., Tarján A., Horváth G. Az új pszichoaktív szerek monitorozása kulcsszakértők bevonásával Magyarországon 2017-2018-ban. Nemzeti Drog Fókuszpont. 2018.

6. Kobets P. N., Krasnova K. A. International Law Enforcement Cooperation in Countering Illicit Drug Trafficking. Legal Science in the 21st Century: Current Problems and Prospects for Their Solutions. Shakhty, 2020, pp. 127-129.

7. Lévai M. A kábitószer-probléma és a bünözés összefüggései. Kandidátusi értekezés. Miskolc, 1991. 229 p.

8. Mátyás S. A szervezett bünözés kriminálgeográfiai vizsgálata. Nemzetközi jellegü szervezett bünözés nyomozásának kutatása információáramlási szempontból. Vol. I. Budapest, Nemzeti közszolgálati Egyetem Publ., 2018, pp. 134-168. 
9. Romposné Kovács É. Designer drog - új pszichoaktív anyag - kábítószer: A terület jogi szabályozásának a változása, hiányosságai és azok hatása a vegyészszakértői tevékenységre. Doktori Mühelytanulmányok: A jogtudomány sajátossága. Győr, Széchenyi István Egyetem Publ., 2017, pp. 285-296.

10. Sivadó M. Jelenkori drogpolitika Magyarországon és Európában, tengerentúli kitekintéssel. Studia Doctorandum Alumnae. Budapest, Pytheas Publ., 2017, pp. 11-265.

11. Tihanyi M. Rendőri intézkedések kábítószer fogyasztás esetén Rendészeti ismeretek a kábitószer problémával kapcsolatban. Igazságügyi és Rendészeti Minisztérium. Budapest, 2009.

12. Ürmösné S. G. Technical English for Officers. Budapest, Dialóg Campus Publ., 2018.

13. Zhesterov P. V. Prospects of Economy of Criminal Repression Measures in Illegal Drug Trafficking in the CARICC Member States. International Criminal Law and International Justice, 2020, no. 6, pp. 12-15.

Дата поступления статьи $\mid$ Article received date

16.09.2020

Дата поступления после рецензирования и доработки $\mid$ Article after peer review and revision received date 17.11.2020

Дата приема к публикации | Article accepted date 24.11.2020 